\title{
TATA LAKSANA INFEKSI INTRAABDOMEN DENGAN PENYULIT SYOK SEPSIS DAN ACUTE KIDNEY INJURY
}

\author{
Dian Wirdiyana ${ }^{1}$ Faisal $^{2}$ \\ 1, 2Program Pendidikan Konsultan Intensive Care Fakultas Kedokteran Universitas Hasanuddin, \\ Makassar, Indonesia \\ RSUP Wahidin Sudirohusodo Makassar \\ Email: ${ }^{1}$ wirdiyanadian@gmail.com ${ }^{2}$ faisal_kedok@yahoo.com
}

\begin{abstract}
Abstrak
Infeksi intraabdomen merupakan penyebab kedua tertinggi mortalitas yang berkaitan dengan infeksi di ICU. Infeksi intraabdomen sering dihubungkan dengan kejadian syok sepsis dan Acute Kidney Injury (AKI) dibandingkan dengan infeksi dari tempat lain. Pasien yang mengalami sepsis karena infeksi intraabdomen sebaiknya dilakukan kontrol sumber infeksi, perawatan di ICU dan terapi antimikroba yang tepat untuk mencegah komplikasi. Dilaporkan kasus pasien laki-laki, 20 tahun, dengan diagnosa infeksi intraabdomen disertai penyulit syok sepsis dan AKI, dilakukan tata laksana operasi laparotomy explorasi dan ileostomy serta tindakan Continues Renal Replacement Theraphy (CRRT). Telah dilaporkan sebuah kasus keberhasilan dan keamanan penerapan CRRT pada pasien peritonitis generalisata dengan penyulit syok sepsis dan AKI di ICU. Terapi ini dapat dipertimbangkan sebagai salah satu pilihan pada pasien dengan masalah yang sama bila sarana dan prasarana tersedia.
\end{abstract}

Kata kunci: Infeksi inraabdomen, Sepsis, AKI, CRRT.

\section{Pendahuluan}

Sepsis adalah keadaan disfungsi organ yang mengancam jiwa yang disebabkan oleh disregulasi respon tubuh terhadap infeksi. Sepsis dan syok sepsis menjadi masalah utama pada penanganan pasien kritis karena tingginya angka mortalitas. Identifikasi dan penanganan yang tepat pada jam pertama setelah diagnosa sepsis memberikan hasil yang lebih baik. ${ }^{1,2}$

Infeksi intraabdomen merupakan penyebab kedua tertinggi mortalitas yang berkaitan dengan infeksi di ICU. Infeksi intraabdomen sering dihubungkan dengan kejadian syok sepsis dan Acute Kidney Injury (AKI) dibandingkan dengan infeksi dari tempat lain. Mortalitas infeksi intraabdomen yang sudah mengalami sepsis berkisar 3060\%. Pasien yang mengalami sepsis karena infeksi intraabdomen sebaiknya dilakukan kontrol sumber infeksi, perawatan di ICU dan terapi antimikroba yang tepat untuk mencegah komplikasi dan untuk perbaikan yang lebih baik. $^{3,4}$

Pada pasien sakit kritis dengan sepsis saat pasien menjalani perawatan di Intensive Care Unit dapat mengalami kegagalan fungsi organ terutama pada sistem pernapasan $(43 \%)$ dan sistem renal (36\%). Sepsis adalah salah satu penyebab Acute Kidney Injury pada pasien sakit kritis yang dirawat di ICU yang dikenal dengan Sepsis-associated AKI (SA-AKI). Angka morbiditas dan mortalitas SA-AKI masih cukup tinggi meskipun perkembangan teknologi perawatan supportif sudah semakin maju. Pemahaman yang baik tentang SA-AKI diharapkan dapat meningkatkan kewaspadaan dan membuat keputusan inisiasi penatalaksanaan yang sesuai sehingga dapat memberikan luaran yang lebih baik pada 
pasien dengan SA-AKI di ICU. ${ }^{5}$

\section{Laporan Kasus}

Pasien laki-laki (Tn. A), umur 20 tahun, berat badan (BB) 60 kilogram (kg), masuk ke Instalasi Rawat Darurat (IRD) Rumah Sakit Wahidin Sudirohusodo (RSWS), tanggal 2 September 2019, akibat trauma tumpul abdomen, 22 jam sebelum masuk rumah sakit (MRS). Pada pemeriksaan fisik di IRD, keadaan umum tampak sakit berat dengan kesadaran compos mentis (gelisah), jalan napas yang paten, pernapasan spontan, frekuensi napas (respiratory rate/RR) $35 \mathrm{x} /$ menit, tekanan darah (TD) 94/68 mmHg, laju jantung (heart rate/HR) 140 x/menit, GCS 14 (E3M6V5), dan suhu $36,5^{\circ} \mathrm{C}$. Pada pemeriksaan abdomen didapatkan nyeri tekan seluruh daerah perut dengan bising usus yang melemah, serta produksi urine $20 \mathrm{cc} / \mathrm{jam}$ dengan warna kuning pekat.

Pasien diberikan terapi oksigen dengan NRM 8 1/menit dan resusitasi cairan dengan kristaloid Ringer Laktat (RL) 1800 cc 1 jam pertama, dan dilanjutkan cairan maintanance 25 tetes/menit. Selanjutnya diberikan antibiotika profilaksis ceftriaxone 2 gr/iv dan metronidazole 500 mg/iv. Kemudian dari pemeriksaan lanjutan didapatkan hasil pemeriksaan laboratorium: hemokonsentrasi dengan haemoglobin/Hb 19,8 gr/dL, hematokrit/Hct 54,0\%, leukopeni (WBC 3100/uL), dan trombosit normal (174.000). Dari pemeriksaan kimia darah diperoleh :
PT/APTT memanjang 17,0/38,8 detik serta INR 1,68; kadar glukosa darah (GDS) 109 $\mathrm{mg} / \mathrm{dL}$, peningkatan ureum (Ur) $57 \mathrm{mg} / \mathrm{dL}$ dan creatinin $(\mathrm{Cr}) 2,28 \mathrm{mg} / \mathrm{dL}, \mathrm{SGOT} / \mathrm{SGPT}$ 20/11 u/l, dan kadar albumin 2,6 gr/dL, serta $\mathrm{Na} / \mathrm{K} / \mathrm{Cl}=133 / 4,7 / 100 \mathrm{mmol} / \mathrm{L}$. Selain itu diperoleh hasil prokalsitonin (PCT) yang sangat tinggi, yaitu > $200 \mathrm{ng} / \mathrm{mL}$.

Pada pemeriksaan foto thoraks didapatkan gambaran Pneumoperitonium kanan.

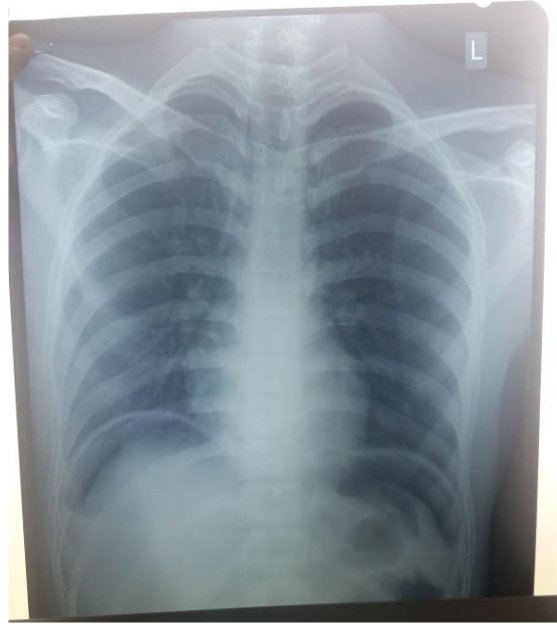

Gambar 1. Pemeriksaan Radiologi Chest X Ray (2September 2019)

Dari hasil pemeriksaan di atas pasien didiagnosis dengan sepsis + peritonitis generalisata et causa suspek perforasi hollow viscus.

Kemudian pasien diputuskan untuk menjalani operasi laparotomy explorasi dan ileostomy dengan general anestesi dan operasi berlangsung selama 2 jam. Selama operasi, tekanan darah intraoperatif: tekanan darah sistolik (TDS) 70-120 mmHg, tekanan darah diastolik (TDD) 35-60 mmHg, dan HR 150 $\mathrm{x} /$ menit, dengan support vasopressor norepinefrin dosis $0,1-0,2 \mathrm{mcg} / \mathrm{kgBB} / \mathrm{unit}$. 
Perdarahan berkisar $100 \mathrm{cc}$ dan produksi urine

60 cc. Pasien menerima cairan intravena kristaloid 2000 cc. Selesai operasi, pasien tidak diekstubasi dan ditransfer ke ICU.

\section{Awal Masuk ICU}

Pasien masuk ICU tanggal 03/09/2019 pukul 00.30.

Dari pemeriksaan fisis pasien ditemukan:

B1 : O2 Via ETT On Ventilator Mode Pressure Control ventilation (PCV), RR $16 \mathrm{x} / \mathrm{menit}$, PEEP 5, PS 10. Dengan hasil luaran: TV 360-400 mL, SpO2 98$99 \%, \mathrm{FiO}_{2} 100 \%$ dititrasi hingga $60 \%$.

B2 : TD 72/55 mmHg, MAP $60 \mathrm{mmHg}$, HR $160 \mathrm{x} / \mathrm{mnt}$ reguler, kuat angkat, akral hangat, CRT $<2$ detik.

B3 : GCS tersedasi, pupil bulat isokor 2,5 $\mathrm{mm} / 2,5 \mathrm{~mm}, \mathrm{RC}(+/+)$, Temp $38,5^{\circ} \mathrm{C}$.

B4 : Urine perkateter, produksi $30 \mathrm{cc} / \mathrm{jam}$, warna kuning pekat

B5 : Tympanik, supel, datar, peristaltik usus $(+)$, defekasi (-)

B6 : Edema (+/+), sianosis (-), fraktur (-/-)

Pasien didiagnosis dengan syok sepsis ec peritonitis generalisata ec perforasi hollow viscus + AKI stage II + Koagulopati + Hipoalbuminemia. Tindakan awal di ICU mencakup:

a. Ventilasi mekanik (VM) dengan strategi proteksi paru.

Mode Pressure Control ventilation (PCV), RR 16 x/menit, PEEP 5, PS 10. Dengan hasil luaran: TV 360-400 mL, SpO2 98$99 \%, \mathrm{FiO}_{2} 100 \%$ dititrasi hingga $60 \%$.

b. Pemeriksaan vena cava inferior (IVC) dengan USG bedside kesan isi cukup dengan variabilitas $<50 \%$. Untuk mencapai $\mathrm{MAP} \geq 65 \mathrm{mmHg}$ dilanjutkan pemberian vasopressor dini secara titrasi: norepinefrin $0,1-0,4 \mu \mathrm{g} / \mathrm{kgBB} /$ menit.

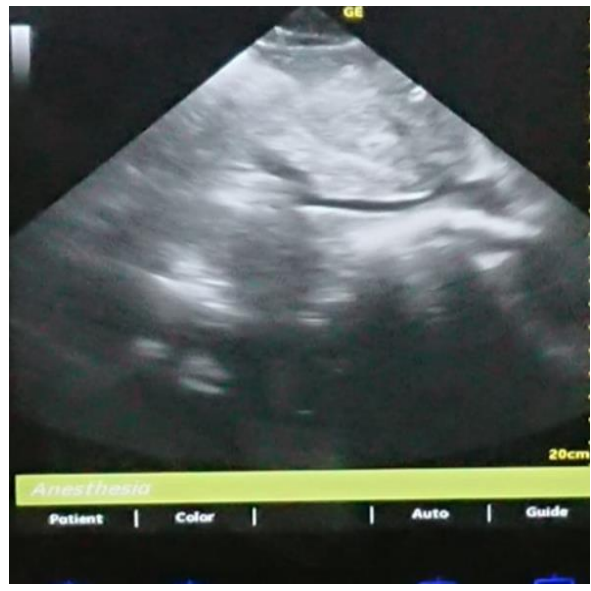

Gambar 2. Pemeriksaan USG vena cava inferior (3 September 2019, HP-1)

c. Pemasangan (CVC) $\rightarrow$ CVP $10 \mathrm{mmHg}$ dan $\mathrm{ScVO}_{2} 89,9 \%$

\section{d. Pemasangan arterial line}

e. Head Up $30-45^{\circ}$

Dari analisis gas darah diperoleh asidosis metabolik dengan $\mathrm{pH} 7,111, \mathrm{PCO}_{2}$ 17,8 mmHg, $\mathrm{PO}_{2} 78 \mathrm{mmHg}, \mathrm{HCO} 3$ 9,2, BE 16, P/F Ratio 130 dan $\mathrm{SCVO}_{2} 89,9$, dengan $\mathrm{FiO}_{2}$ 0,6. Kadar laktat sangat tinggi, yaitu 6,2 $\mathrm{mmol} / \mathrm{L}$. MAP pasca resusitasi mencapai 80 mmHg dan produksi urine $30 \mathrm{cc} / \mathrm{jam}$.

\section{Perawatan ICU}

Dari hasil pemeriksaan, ditemukan pasien sakit kritis dengan skor APACHE II 27 dengan mortalitas $35 \%$. Perjalanan penyakit, rencana, serta tindakan yang dilakukan selama perawatan ICU telah dirangkum pada Tabel 6. Selama perawatan di ICU, pada pasien ini ditemukan syok sepsis, acute kidney injury, asidosis metabolik, koagulopati, serta hipoalbuminemia. Tindakan yang dilakukan 
beserta target dan hasil progresi pasien mencakup:

\section{a. Ventilasi Mekanik}

Pasien ini menerima ventilasi mekanik (VM) dengan strategi proteksi paru selama 6 hari melalui ETT (endotracheal tube). Pasien menerima VM mode $P C V$ selama 2 hari perawatan di ICU dan SIMV-PC selama 4 hari perawatan di ICU. Tidal volume (dalam batas 360 - $400 \mathrm{cc}$ ) dan frekuensi napas ventilator diatur untuk mencapai minute volume (MV) yang dapat mempertahankan $\mathrm{PaCO}_{2}$ dalam batas 30-45 mmHg (EtCO 2 lebih rendah). PEEP diberikan $5 \mathrm{cmH}_{2} \mathrm{O}$, PS pada kisaran 510. PIP ditargetkan maksimal $30 \mathrm{cmH}_{2} \mathrm{O}$ dan $P / F$ ratio ditargetkan mencapai rasio $>300$.

\section{b. Manajemen Cairan}

Cairan pemeliharaan yang diberikan adalah Ringer Laktat 500-1000 cc dan Dekstrosa 5\% 500 cc. Pada HP Ke-3 dilakukan pemberian cairan parenteral Aminofluid 500 cc. Pencapaian CVP dalam kisaran $4-8 \mathrm{mmHg}$.

\section{c. Vasopressor dan Inotropik}

Pada periode dimana MAP $<65$ $\mathrm{mmHg}$ diberikan topangan norepinefrin 0,1 $0,4 \mathrm{mcg} / \mathrm{kgBB} / \mathrm{menit}$, vasopressin 0,03 unit/jam dan dobutamin 5-10 $\mathrm{mcg} / \mathrm{kgBB} / \mathrm{menit}$.

\section{d. Transfusi Albumin}

Pemberian albumin 25\% $100 \mathrm{cc}$ per 24 jam selama 3 hari perawatan diberikan bersamaan pada saat CRRT.

\section{e. Antibiotik}

Pasien ini menerima terapi meropenem $1 \mathrm{gr} / 8$ jam/iv dari HP ke-1 sampai HP ke-10.

\section{f. Diuresis Farmakologi}

Terjadi fluid overload > 10\%, produksi urine $<0,5 \mathrm{cc} / \mathrm{kgBB} / \mathrm{jam}$ dan hasil pemeriksaan ureum/kreatinin naik dari 57/2,24 menjadi 72/2,80 sehingga diberikan diuresis farmakologi yakni furosemide stress test terlebih dahulu dengan bolus furosemide $60 \mathrm{mg} / \mathrm{iv}$ kemudian dinilai produksi urine selama 2 jam, didapatkan $200 \mathrm{ml}$ dalam 2 jam sehingga dilanjutkan dengan furosemide 10 $\mathrm{mg} / \mathrm{jam} / \mathrm{SP}$.

\section{g. Continuous Renal Replacement Therapy (CRRT) \\ CRRT pada pasien ini dilakukan pada} hari ke-4, 5, dan 6 perawatan di ICU. Dengan fluid removal sekitar $30 \mathrm{cc}$ per jam.

Pemeriksaan persentase fluid overload (FO) selama perawatan di ICU $<10 \%$, kecuali pada hari perawatan pertama dan keempat, terjadi balans cairan kumulatif $(+)$, fluid overload $>10 \%$, dengan CVP sekitar 10$12 \mathrm{mmHg}$ dan produksi urine $0 \mathrm{cc}$ per jam hingga 30 cc per jam (Tabel 1).

F: Pasien puasa pada HP ke-0 sampai HP ke5. Nutrisi parenteral dimulai pada HP ke-3 tiga sampai HP ke-5. Untuk selanjutnya nutrisi enteral menjadi prioritas dengan tahapan sebagai berikut: Clear fluid pada HP ke-3 tapi residu mulai berkurang pada HP ke6, dan kemudian susu 250 kcal mulai diberikan, selanjutnya ditingkatkan dan 
ditambahkan bubur saring dan jus buah hingga 1500 kkal pada HP ke-9.

$\checkmark$ A : Analgesia pada HP ke-0 hingga HP ke-5 adalah fentanyl 20-50 mcg/jam/sp dan paracetamol $1 \mathrm{gr} / 6 \mathrm{jam} / \mathrm{iv}$.

$\checkmark \mathbf{S}$ : Sedasi pada hari pertama hingga kelima adalah Midazolam $3 \mathrm{mg} / \mathrm{jam} / \mathrm{sp}$

$\checkmark \mathbf{T}:-$

$\checkmark$ H : Head Up $30^{\circ}$

$\checkmark \mathbf{U}$ : Omeprazol $40 \mathrm{mg} / 24 \mathrm{jam}$

$\checkmark$ G : GDS ditargetkan $120-180 \mathrm{mg} / \mathrm{dL}$.

Tabel Rangkuman penilaian, rencana, dan tindakan selama hari perawatan di ICU.

\begin{tabular}{|c|c|c|c|}
\hline $\begin{array}{c}\text { HP } \\
\text { Dan } \\
\text { Tgl }\end{array}$ & Assessment & Rencana & Tindakan* \\
\hline $\begin{array}{c}\mathrm{Ke}-1 \\
03 / 0 \\
9 / \\
2019\end{array}$ & $\begin{array}{l}\text { - Post op } \\
\text { laparotom } \\
\text { i explorasi } \\
+ \\
\text { ileostomy } \\
\text { ec } \\
\text { peritonitis } \\
\text { - Syok } \\
\text { sepsis } \\
\text { - AKI stage } \\
\text { II } \\
\text { - Koagulop } \\
\text { ati } \\
\text { - Hipoalbu } \\
\text { minemia }\end{array}$ & $\begin{array}{l}\text { - Ventilator } \\
\text { mekanik + } \\
\text { Manajeme } \\
\mathrm{n} \\
\text { ventilator } \\
\text { bundle } \\
\text { - Proteksi } \\
\text { lung } \\
\text { strategi } \\
\text { - Monitorin } \\
\text { g } \\
\text { Hemodina } \\
\text { mik } \\
\text { - Antibiotik } \\
\text { spektrum } \\
\text { luas } \\
\text { - Kultur } \\
\text { darah serta } \\
\text { sensitivitas } \\
\text { antibiotik } \\
\text { - Negative } \\
\text { fluid } \\
\text { balance }\end{array}$ & $\begin{array}{l}\text { - F: Puasa } \\
\text { - A: Fentanyl } 30 \\
\text { mcg/jam/sp/iv + } \\
\text { Paracetamol } 1 \\
\text { gr/6jam/iv } \\
\text { - S:Midazolam } 2 \\
\text { mg/jam/sp/iv } \\
\text { - T: - } \\
\text { - H: Head up 30 } \\
\text { - U: Omeprazole } 40 \\
\text { mg/24jam/iv } \\
\text { - G: Target GDS } \\
\text { 120-180 mg/dL } \\
\text { - S: O2 via ETT on } \\
\text { Ventilator Mode } \\
\text { Pressure Control } \\
\text { ventilation (PCV), } \\
\text { RR } 16 \text { x/menit, } \\
\text { PEEP 5, PS 10, } \\
\text { FIO } 60 \% \\
\text { B: - } \\
\text { - I: IVFD RL 1000 } \\
\text { cc/24 jam, D5\% } \\
\text { 500cc/24 jam } \\
\text { D: Meropenem } 1 \\
\text { gr/8jam/iv } \\
\text { Norepinefrin 0,1-0,4 } \\
\text { mcg/ kgBB/ menit } \\
\text { Vasopressin 0,04 } \\
\text { unit/jam/sp } \\
\text { Dobutamin 5-10 } \\
\text { mcg/kgBB/menit } \\
\text { Asam Tranexamat } \\
\text { 500 mg/8jam/iv } \\
\text { Furosemida bolus } 60 \\
\text { mg lalu dilanjutkan } \\
\text { 5-10 mg/jam/sp } \\
\text { Methylprednisolon } \\
\text { bolus 62,5 mg lalu } \\
\text { dilanjutkan 62,5 } \\
\text { mg/24 jam/sp }\end{array}$ \\
\hline
\end{tabular}

\begin{tabular}{|c|c|c|c|}
\hline & & & \begin{tabular}{|c|} 
Keb. Cairan: 2100 \\
cc/24 jam \\
Keb. Kalori: 1500 \\
kkal/24jam \\
\end{tabular} \\
\hline $\begin{array}{l}\mathrm{Ke}-2 \\
04 / 0 \\
9 \\
2019\end{array}$ & $\begin{array}{l}\text { - Post op } \\
\text { laparotom } \\
\text { i explorasi } \\
+ \\
\text { ileostomy } \\
\text { ec } \\
\text { peritonitis } \\
\text { - Syok } \\
\text { sepsis } \\
\text { - AKI stage } \\
\text { II } \\
\text { - Koagulop } \\
\text { ati } \\
\text { - Hipoalbu } \\
\text { minemia }\end{array}$ & & $\begin{array}{l}\text { - F: Puasa } \\
\text { Terapi dilanjutkan }\end{array}$ \\
\hline $\begin{array}{l}\mathrm{Ke}-3 \\
05 / 0 \\
9 \\
2019\end{array}$ & $\begin{array}{l}\text { - Post op } \\
\text { laparotomi } \\
\text { explorasi } \\
+ \\
\text { ileostomy } \\
\text { ec } \\
\text { peritonitis } \\
\text { - Syok } \\
\text { sepsis } \\
\text { - AKI Stage } \\
\text { II } \\
\text { - Koagulop } \\
\text { ati } \\
\text { - Hipoalbu } \\
\text { minemia }\end{array}$ & $\begin{array}{l}\text { - Pemasanga } \\
\text { n DLC di } \\
\text { vena } \\
\text { jugular } \\
\text { Persiapan } \\
\text { CRRT }\end{array}$ & $\begin{array}{l}\text { - F: Clearfluid D5\% } \\
\text { 5x50 ml via NGT } \\
\text { (cek residu tiap } 4 \\
\text { jam) } \\
\text { - I: IVFD RL 500 } \\
\text { cc/24 jam, D5\% } \\
500 \mathrm{cc} / 24 \text { jam, } \\
\text { aminofluid 500 } \\
\text { cc/24 jam } \\
\text { - S: O2 via ETT on } \\
\text { Ventilator Mode } \\
\text { SIMV PC, RR 14x, } \\
\text { PInsp 10 cmH2O, } \\
\text { PEEP 5, PS 8, } \\
\text { FIO2 40 }\end{array}$ \\
\hline $\begin{array}{l}\mathrm{Ke}-4 \\
06 / 0 \\
9 \\
2019\end{array}$ & $\begin{array}{l}\text { - Post op } \\
\text { laparotomi } \\
\text { explorasi } \\
+ \\
\text { ileostomy } \\
\text { ec } \\
\text { Peritonitis } \\
\text { - Syok } \\
\text { Sepsis } \\
\text { - AKI stage } \\
\text { II } \\
\text { - Koagulop } \\
\text { ati } \\
\text { - Hipoalbu } \\
\text { minemia }\end{array}$ & $\begin{array}{l}\text { CRRT } 24 \\
\text { jam: fluid } \\
\text { removal } \\
30 \mathrm{cc} / \mathrm{jam}\end{array}$ & $\begin{array}{l}\text { - F: Clear fluid D5\% } \\
\text { 5x100 ml via NGT } \\
\text { I: IVFD RL 500 } \\
\text { cc/24 jam, D5\% } \\
500 \mathrm{cc} / 24 \text { jam, } \\
\text { aminofluid } 500 \\
\text { cc/24 jam, human } \\
\text { albumin } 25 \% 100 \\
\text { cc/24 jam }\end{array}$ \\
\hline $\begin{array}{l}\mathrm{Ke}-5 \\
07 / 0 \\
9 \\
2019\end{array}$ & $\begin{array}{l}\text { - Post op } \\
\text { laparotomi } \\
\text { explorasi } \\
+ \\
\text { ileostomy } \\
\text { ec } \\
\text { peritonitis } \\
\text { - Syok } \\
\text { sepsis } \\
\text { - Koagulop } \\
\text { ati } \\
\text { - Hipoalbu } \\
\text { minemia }\end{array}$ & $\begin{array}{l}\text { Melanjutkan } \\
\text { CRRT: } \\
\text { fluid } \\
\text { removal } 30 \\
\text { cc / jam }\end{array}$ & $\begin{array}{l}\text { - Puasa } \\
\text { - I: IVFD RL 500 } \\
\text { cc/24 jam, D5\% } \\
500 \mathrm{cc} / 24 \text { jam, } \\
\text { aminofluid } 500 \\
\text { cc/24 jam, human } \\
\text { albumin 25\% } 100 \\
\text { cc/24 jam } \\
\text { - D: } \\
\text { Norepinefrin 0,05 } \\
\text { mcg/kgbb/menit } \\
\text { Furosemide 5 } \\
\text { mg/jam/sp } \\
\text { Stop Methylprednison }\end{array}$ \\
\hline
\end{tabular}




\begin{tabular}{|c|c|c|c|}
\hline $\begin{array}{l}\text { Ke-6 } \\
08 / 0 \\
9 \\
2019\end{array}$ & $\begin{array}{l}\text { - Post op } \\
\text { Laparoto } \\
\text { mi } \\
\text { explorasi } \\
+ \\
\text { ileostomy } \\
\text { ec } \\
\text { peritonitis } \\
\text { - Syok } \\
\text { sepsis } \\
\text { - Koagulop } \\
\text { ati } \\
\text { - Hipoalbu } \\
\text { minemia }\end{array}$ & $\begin{array}{l}\text { - Weaning } \\
\text { \& } \\
\text { Liberation } \\
\text { of } \\
\text { Ventilator } \\
\text { - Monitorin } \\
\mathrm{g} \\
\text { hemodina } \\
\text { mik, } \\
\text { weaning } \\
\text { vasopresso } \\
\text { r dan } \\
\text { inotropik } \\
\text { - Hari } \\
\text { terakhir } \\
\text { CRRT }\end{array}$ & $\begin{array}{l}\text { - } \text { EKSTUBASI } \\
\text { - F: Peptisol 5X50 } \\
\text { kkal } \\
\text { - I: IVFD RL 500 } \\
\text { cc/24 jam, D5\% } \\
500 \text { cc/24 jam, } \\
\text { aminofluid 500 } \\
\text { cc/24 jam, human } \\
\text { albumin 25\% } 100 \\
\text { cc/24 jam } \\
\text { D: } \\
\text { Stop Dobutamin } \\
\text { Stop Midazolam } \\
\text { dan fentanyl } \\
\text { Stop Furosemida }\end{array}$ \\
\hline $\begin{array}{l}\mathrm{Ke}-7 \\
09 / 0 \\
9 \\
2019\end{array}$ & $\begin{array}{l}\text { - Post op } \\
\text { laparotomi } \\
\text { explorasi } \\
+ \\
\text { ileostomy } \\
\text { ec } \\
\text { peritonitis } \\
\text { - Hipoalbu } \\
\text { minemia }\end{array}$ & $\begin{array}{l}\text { - Monitorin } \\
\mathrm{g} \\
\text { hemodina } \\
\text { mik } \\
\text { Pindah HCU }\end{array}$ & $\begin{array}{l}\text { - F : Peptisol 3x100 } \\
\text { cc, Bubur saring } \\
\text { 3x150 cc } \\
\text { - I: IVFD RL 500 } \\
\text { cc/24 jam, D5\% } \\
500 \mathrm{cc} / 24 \mathrm{jam} \\
\text { - } \mathrm{O}_{2} \text { via nasal } \\
\text { cannula } 21 / \text { menit } \\
\text { - D: } \\
\text { Norepinefrin } \\
\text { 0,03mcg/kgBB/me } \\
\text { nit } \\
\text { Stop Vasopressin } \\
\text { Stop Dobutamin }\end{array}$ \\
\hline $\begin{array}{l}\mathrm{Ke}-8 \\
10 / 9 \\
2019\end{array}$ & $\begin{array}{l}\text { - Post op } \\
\text { laparotomi } \\
\text { explorasi } \\
+ \\
\text { ileostomy } \\
\text { ec } \\
\text { peritonitis } \\
\text { - Hipoalbu } \\
\text { minemia }\end{array}$ & $\begin{array}{l}\text { Pindah } \\
\text { ruangan } \\
\text { perawatan } \\
\text { biasa }\end{array}$ & $\begin{array}{l}\text { - F : Peptisol 3x200 } \\
\text { cc, Bubur saring } \\
3 \times 150 \mathrm{cc}, \text { jus buah } \\
1 \times 100 \mathrm{cc}\end{array}$ \\
\hline
\end{tabular}

*Penulisan untuk tindakan yang sama tidak diulang.

\section{Hasil pemeriksaan kultur dan Sensitivitas}

Pemeriksaan Tanggal 3 September 2019 dengan hasil Tanggal 08 September 2019: Tidak ada pertumbuhan.

\section{Diskusi}

Sepsis merupakan disfungsi organ yang mengancam jiwa akibat disregulasi respon tubuh terhadap infeksi. Dengan demikian

sepsis dan syok sepsis termasuk dalam kategori kedaruratan medis sehingga direkomendasikan oleh SSC bahwa pengobatan dan resusitasi harus dimulai segera. Kriteria diagnostik sepsis yang terbaru berdasarkan disfungsi organ yang terjadi, melalui skoring qSOFA dan SOFA. Jika qSOFA positif selanjutnya dilakukan skoring dengan metode SOFA. Pada pasien ini didapatkan hipotensi, dan takipnea, yang secara penapisan memenuhi 2 dari 3 kriteria qSOFA (Glasgow Coma Scale 13 atau kurang, tekanan darah sistolik $100 \mathrm{mmHg}$ atau kurang, serta laju napas $22 \mathrm{kali} / \mathrm{menit}$ atau lebih). Sedangkan skor SOFA pada pasien ini didapatkan: 13, yakni sistem respirasi ( $\mathrm{PaO} 2 / \mathrm{FiO} 2):<200 \mathrm{mmHg}$ dengan alat bantu napas (3), koagulasi (platelet): 174.000 (0), liver $\quad$ (bilirubin): $\quad 0,9 \quad \mu \mathrm{mol} / \mathrm{L} \quad(0)$, kardiovaskuler: norepinefrin > 0,1 (4), Sistem Saraf Pusat (skor GCS): 13-14 (1), dan Renal: kreatinin mg/dL 2,28 $\mu \mathrm{mol} / \mathrm{L}$ (2) dan produksi urine $<500 \mathrm{ml} /$ hari (3). Apabila pasien yang mengalami infeksi didapatkan skor SOFA $\geq 2$ maka sudah tegak diagnosis sepsis. Pasien ini didiagnosis syok sepsis dengan adanya klinis sepsis dengan hipotensi menetap yang membutuhkan vasopressor untuk mempertahankan MAP $\geq 65 \mathrm{mmHg}$ dan kadar laktat serum $>2 \mathrm{mmol} / \mathrm{l}^{6}$

Resusitasi inisial mempunyai peranan penting dalam penatalaksanaan sepsis dan syok sepsis. Panduan SSC tahun 2016 memberikan sedikit keleluasaan dalam melakukan penilaian hemodinamika, dalam hal pemeriksaan fisik dan penilaian variable fisiologis berdasarkan sumber daya yang tersedia pada setiap institusi. Yang perlu 
diperhatikan bahwa penilaian hemodinamika pada pasien sepsis dan syok sepsis memegang peranan penting sebelum resusitasi inisial dilakukan; apakah pasien tersebut membutuhkan cairan tambahan atau tidak, berapa jumlah yang dibutuhkan, berapa lama, dan target apa yang akan dicapai dalam tatalaksana tersebut. Tanpa penilaian yang jelas dan terarah, akan sulit menentukan apakah masih membutuhkan cairan resusitasi atau sudah mengalami fluid overload. Resusitasi cairan sesuai dengan pedoman resusitasi one hour bundle pada SSC 2018 telah dilakukan di unit rawat darurat. Target minimal resusitasi cairan yaitu produksi urine 30 cc per jam juga tercapai. Laparotomi explorasi dan kolostomi serta pemberian antibiotik untuk mecegah infeksi dan sepsis juga telah dilakukan sebelum pasien masuk ke unit perawatan intensif (ICU). ${ }^{1,7}$

Di awal masuk ICU pasien mengalami inflamasi hebat yang digambarkan oleh kadar prokalsitonin (PCT) yang sangat tinggi, yaitu $>200$ ng/mL. Perfusi jaringan keseluruhan juga tidak adekuat, dimana dari analisis gas darah ditemukan asidosis metabolik kompensasi respiratorik $(\mathrm{pH}$ 7,11) akibat peningkatan kadar asam laktat $(6,2 \mathrm{mmol} / \mathrm{L})$, $\mathrm{ScVO}_{2} 89,9, \mathrm{PCO}_{2}$ gap > 7, MAP berkisar 60 $\mathrm{mmHg}$ serta produksi urine berkisar $30 \mathrm{cc} / \mathrm{jam}$ (0,5 cc/kgBB/jam).

Pada pasien ini, awal masuk ICU kami tidak melakukan resusitasi cairan lagi karena melalui pemeriksaan IVC (USG bedside) didapatkan preload dengan kesan cukup dan
$\mathrm{ScVO}_{2} 89,9$. Rekomendasi target MAP awal pada pasien syok septik yang membutuhkan vasopressor menurut SSC adalah $65 \mathrm{mmHg}$. Target MAP $\geq 65 \mathrm{mmHg}$ merupakan parameter makrosirkulasi yang secara umum harus dicapai sesegera mungkin. Hipotensi arterial yang berkepanjangan dapat mengakibatkan syok yang irreversible dan meningkatkan mortalitas. Dengan demikian upaya resusitasi awal, termasuk pemberian cairan yang adekuat serta penggunaan vasopressor lebih dini pada kasus-kasus hipotensi yang mengancam jiwa diharapkan akan meningkatkan angka keberhasilan. Sehingga pada pasien ini, untuk mencapai target $\mathrm{MAP} \geq 65 \mathrm{mmHg}$, diberikan vasopressor dini, yakni: norepinefrin $0,1-0,4$ $\mathrm{mcg} / \mathrm{kgBB} / \mathrm{menit}$. Untuk mengurangi dosis norepinefrin kami memberikan vasopressin dosis 0,04 unit/jam. Kami juga memberikan dobutamine 5-10 $\mathrm{mcg} / \mathrm{kgBB} / \mathrm{menit}$ pada pasien ini karena adanya tanda hipoperfusi meskipun sudah diberikan cairan adekuat dan vasopressor, yakni hiperlaktatemia disertai tingginya $\mathrm{ScVO}_{2}$ meskipun kadar $\mathrm{Hb}$ dan preload telah mencukupi, dan juga pada pemeriksaan Echocardiografi didapatkan kontraksi jantung melemah dengan EF 35\%. Hal ini disesuaikan dengan rekomendasi pada SSC 2016. Semua tindakan resusitasi hemodinamik ini ditujukan untuk meningkatkan penghantaran oksigen $\left(\mathrm{DO}_{2}\right)$. Sedangkan untuk menurunkan konsumsi oksigen $\left(\mathrm{VO}_{2}\right)$ dilakukan pemasangan ventilasi mekanik untuk menunjang respirasi 
serta pemberian obat sedasi midazolam dan analgetik fentanyl. Untuk pemantauan perfusi jaringan pada kasus ini dilakukan pemantauan berulang kadar laktat, saturasi vena sentral $\left(\mathrm{SCVO}_{2}\right)$, dan $\mathrm{PCO}_{2}$ gap.

Tatalaksana cairan yang tepat pada pasien sepsis dan shock sepsis menjadi perhatian khusus. Sepsis Occurance in Acutely Ill Patient (SOAP) studi menyebutkan selain dari parameter umur, balans cairan positif merupakan faktor prognostik yang kuat dari kematian pada pasien sepsis, meskipun skor severitas dari perawatan ICU sama. ${ }^{8}$

Malbrain dkk mengenalkan konsep ROSE (Resusitasi, Optimalisasi, Stabilisasi, Evakuasi) sebagai fase yang akan dialami selama sepsis berlangsung. Pada pasien ini, berdasar dari konsep ROSE, fase resusitasi dan optimalisasi terjadi sesuai pada jam-jam pertama, ketika pasien di IGD. Pemberian Norepinefrin pada pasien ini meningkatkan aliran balik vena sehingga mempunyai efek yang sama dengan pemberian cairan intravena, yaitu peningkatan aliran darah balik vena dan hal ini masuk ke dalam fase resusitasi dari konsep ROSE. Fase evakuasi merupakan tahapan yang terjadi setelah kondisi stabil tercapai, di mana de-resusitasi cairan dilakukan. Pada pasien ini dilakukan de-resusitasi cairan dengan cara pemberian diuretik Furosemida. Sebenarnya Furosemida telah diberikan dalam 24 jam pertama,

sehingga dapat dikatakan bahwa de-resusitasi dini telah dilakukan.
Prowle dkk mengajukan algoritme tatalaksana cairan dalam upaya mencegah ataupun menekan kejadian AKI pada pasien kritis khususnya sepsis. ${ }^{9}$

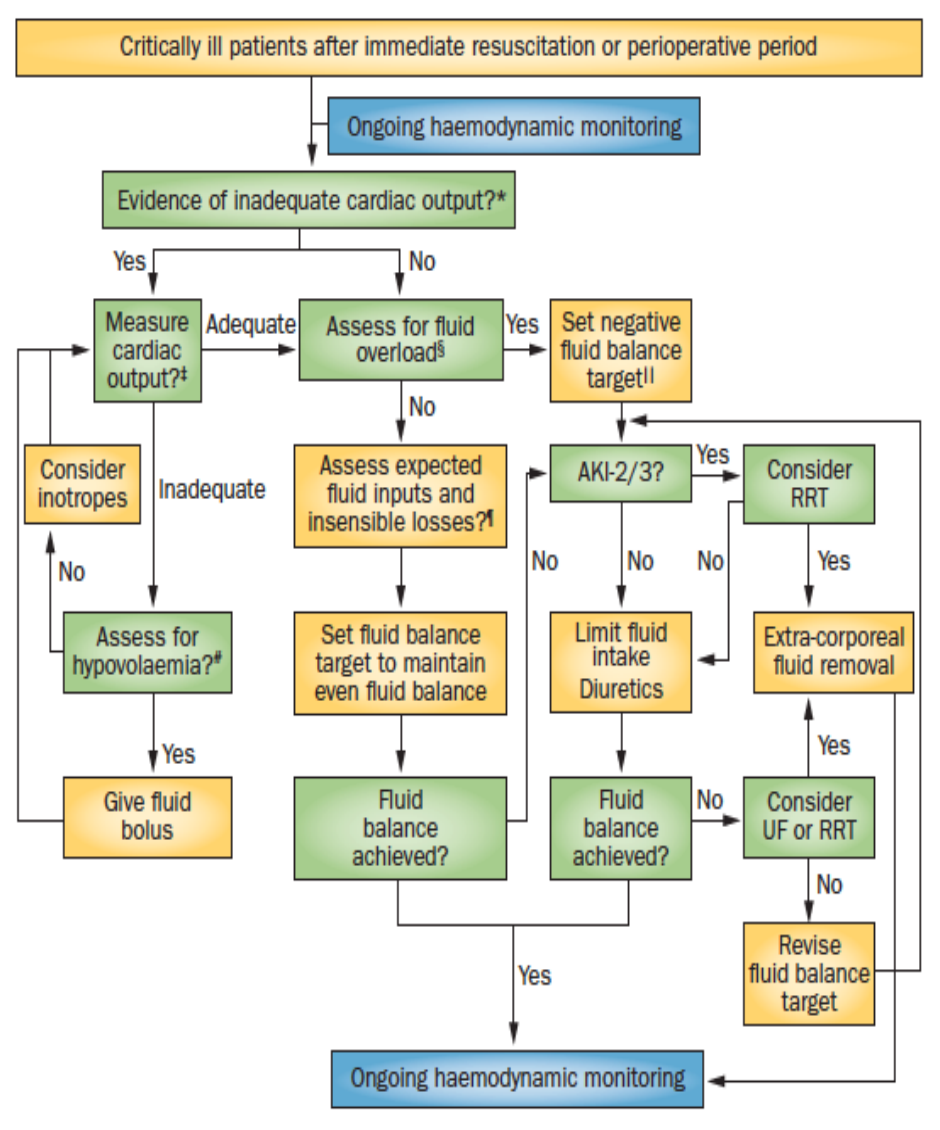

Gambar 6. Manajemen cairan dan hemodinamik setelah fase inisial dari sakit kritis. Sesuai alur ini, tekanan darah arteri yang cukup, dipenuhi dengan pemberian vasopressor, bila diperlukan. Selain dari fluid overload, pada AKI, hemodialisis dilakukan berdasar indikasi hiperkalemia, asidosis ataupun uremia berat. Singkatan: AKI, acute kidney injury, RRT, Renal Replacemnet Therapy, UF, Ultrafiltrasi.

Pada kasus ini, pemberian furosemide dilakukan dengan panduan CVP yang rendah (mendekati $0 \mathrm{mmHg}$ ) dalam menjalankan algoritme seperti pada Gambar 3 di atas. Yang penting untuk diingat, bahwa CVP normal itu 
mendekati nol mmHg dan bukan $8-12 \mathrm{mmHg}$ seperti pada SCC; sehingga resusitasi seharusnya dilakukan dengan pemberian jumlah cairan yang tepat. $\mathrm{CVP}>8 \mathrm{mmHg}$ dihubungkan dengan mortalitas yang lebih tinggi dan meningkatkan resiko AKI pada pasien sepsis dan gagal jantung. Pada percobaan Protocolized Care for Early Septic Shock (ProCESS) dengan target CVP yang lebih rendah daripada Rivers, jumlah cairan yang diberikan lebih sedikit dan penggunaan dini vasopressor memiliki mortalitas pada hari ke-60 yang lebih rendah (21\%) dibandingkan dengan EGDT Rivers. Pada penelitian Legrand dkk didapatkan hubungan antara CVP dan AKI, pada CVP > 4 mmHg; di mana angka kejadian AKI $30 \%$ pada CVP > 6 mmHg dan $80 \%$ pada CVP > $15 \mathrm{mmHg} .{ }^{10}$

Furosemide diberikan dengan tujuan untuk memberikan balans cairan negative yang kemudian karena pasien ini mengalami AKI yang memberat disertai dengan anuri maka dilanjutkan dengan CRRT pada hari ke3 perawatan di ICU. Pada kasus ini, hemodinamik relatif stabil selama dan setelah RRT. CRRT dapat mengeliminasi mediator inflamasi dan cytokines dalam plasma sehingga menyebabkan stabilisasi hemodinamik yang lebih baik dan waktu lama perawatan yang lebih singkat serta mortalitas yang lebih rendah. Jika sepsis atau syok menetap terjadi, luaran pasien tetap saja buruk. Inilah penyebab mengapa beberapa tindakan dilakukan untuk mencegah sepsis yang sangat mudah terjadi pada pasien peritonitis, dan salah satunya adalah CRRT. Mekanisme HVHF dalam memperbaiki hemodinamik masih belum jelas. Pengeluaran sitokin nonspesifik dianggap salah satu manfaat seluruh strategi purifikasi darah pada pasien dengan status disregulasi immuneinflamasi. Saat dilakukan pemeriksaan sitokin, Chung dkk menemukan bahwa kadar sitokin tidak berubah selama 48 jam intervensi dilakukan. Pada pasien kasus ini tidak dilakukan pemeriksaan sitokin, hanya kadar PCT yang menunjukkan penurunan kadar setelah intervensi RRT. ${ }^{11,12}$

Pada pasien ini nilai laktat awal 6,2 $\mathrm{mmol} / \mathrm{L}$, hal ini bisa disebabkan karena ada metabolisme anaerob serta overproduksi laktat dari tubuh. Laktat diproduksi dan dikonsumsi oleh hampir semua sel dalam tubuh. Dalam metabolisme glukosa, kunci pembentukan laktat terletak pada ketersediaan enzim pyruvate dehydrogenase dan oksigen. Kurangnya oksigen dan berlebihnya produksi pyruvate dapat meningkatkan pembentukan laktat. Sehingga pasien dengan syok, peningkatan laktat dapat disebabkan oleh peningkatan produksi akibat hipoksia jaringan, peningkatan metabolisme glukosa, dan penurunan bersihan laktat. Pada penelitian Shapiro tahun 2005, kadar laktat tinggi ( $>4 \mathrm{mmol} / \mathrm{L}$ ) itu dihubungkan dengan angka kejadian kematian dalam 3 hari sebesar $28,4 \%$ sehingga pengukuran kadar laktat plasma merupakan komponen diagnostik dan terapi pada pasien sepsis. ${ }^{13}$ 
Pengendalian infeksi pada pasien ini dengan menggunakan antibiotik baik secara empirik untuk terapi awal dan dilanjutkan dengan terapi target sesuai hasil kultur dan tes sensitivitas. Penggunaan terapi empirik secara kombinasi sesuai dengan rekomendasi SSC 2012 yaitu penggunaan antibiotika kombinasi pada pasien dengan infeksi berat dengan gagal napas dan syok septik, infeksi bakteri pathogen multidrug resistant (MDR) serta pasien dengan kasus yang sulit diterapi. Pemantauan penanda infeksi dilakukan melalui pemeriksaan berulang kadar procalcitonin sebagai penanda utama di samping lekosit dan rasio neutrophil/limfosit. Hasil pemeriksaan kultur darah tidak ditemukan pertumbuhan kuman. Hal ini mungkin saja terjadi karena sample darah untuk kultur diambil setelah pasien dirawat di ICU di mana pasien telah mendapat antibiotika profilaksis sebelum operasi dan kemungkinan cara pengambilan sampel yang salah.

\section{Simpulan}

Telah dilaporkan sebuah kasus keberhasilan dan keamanan penerapan CRRT pada pasien peritonitis generalisata dengan penyulit syok sepsis dan AKI di ICU. Terapi ini dapat dipertimbangkan sebagai salah satu pilihan pada pasien dengan masalah yang sama bila sarana dan prasarana tersedia.

\section{Daftar Pustaka}

1. Rhodes A, Evans L E, Alhazzmi W, Levy M M, Antonelli M, et al. Surviving Sepsis Campaign: International Guidelines for
Management of Sepsis and Septic Shock 2016. In: Dellinger R P, et al. Surviving Sepsis Campaign 2016. SCCM and ESICM 2017. Intensive Care Med. London, England, UK, 2017.

2. Ryotaro Kato and Michael R. Pinsky. Personalizing blood pressure management in septic shock:.Intensive Care (2015) $5: 41$

3. De Waele J, Lipman J, Sakr Y et al. Abdominal infections in the intensive care unit:characteristics, treatment and determinants of outcome. BMC Infect Dis 2014; 14:420

4. Vincent JL, Rello J, Marshall $\mathrm{J}$ et al. International study of the prevalence and outcomes of infection in intensive care units. JAMA 2009; 302: 2323-2329.

5. Yasser Sakr, Suzana M. Lobo, Rui P. Moreno, Herwig Gerlach, V. Marco Ranieri, Argyris Michalopoulus, JeanLouis Vincent. Pattern and early evolution of organ failure and their relation to outcome, prospective study. Crit Care Med 2012; 16(6): R222.

6. Singer, M., Deutschman, C. S., Seymour, C. W., Shankar-Hari, M., Annane, D., Bauer, M., Bellomo, R., Bernard, G. R., Chiche, J.-D. \& Coopersmith, C. M. 2016. The Third International Consensus Definitions For Sepsis And Septic Shock (Sepsis-3). Jama, 315, 801-10.

7. Dellinger RP, Levy MM, Rhodes A et al. Surviving Sepsis Campaign: International Guidelines for Management of Severe 
Sepsis and Septic Shock: 2012. Crit Care Med;41 (2): 580-636.

8. Vincent JL, et al. Sepsis in European intensive care units: Results of the SOAP study. Crit Care Med. 2006; 34: 344-353

9. Prowle JR, et al. Fluid management for the prevention and attenuation of acute kidney injury. Nature Reviews Nephrology. 2014; 10: 37-47.

10. Marik P. E. Iatrogenic salt water drowning and the hazard of a high central venous pressure.Annals of Intensive Care. 2014; 4: 21 .

11. Dahaba A. A., et al. Procalcitonin and proinflammatory cytokine clearance durineg cvvhdf in septic patients. Anaesth Intensive Care. 2002 June; 30(3): 269-74.

12. Zhou F, et al. Blood Purification and Mortality in Sepsis: A Meta-Analysisof Randomized Trials. Crit Care Med. 2013; 41: 2209-2220.

13. Shapiro NI, et al. Serum Lactate as a Predictor of Mortality in Emergency Department Patients With Infection. Annals of Emergency Medicine. 2005; 45: 524-528. 